\title{
Supplications between Politics and Justice: The Northern and Central Italian States in the Early Modern Age*
}

\author{
Cecilia $\mathrm{NubOLA}$
}

"Those who think to do away with petitions would overthrow the entire system of the State". This remark - taken from an anonymous eighteenthcentury account of the political organization of the Duchy of Parma and Piacenza - describes well the importance attributed to complaints in the organization of the state. ${ }^{\mathrm{T}}$ Through complaints, or petitions, it is generally possible to verify a number of fundamental forms and modes of communication between society and the institutions of the ancien regime, and to reconstruct the procedures of mediation, repression, acceptance, and agreement adopted by princes, sovereigns, or magistracies in response to social demands.

Petitions are potentially very flexible instruments and pervade every aspect of social, institutional, administrative, and judiciary life. "Petitioning" refers to different concepts of authority and sovereignty as well as to specific power relations between rulers and those ruled. For this reason, it becomes necessary to take a close look at the relations and differences between various uses of petitions - both from the point of view of the petitioners and from the point of view of the answers provided by the institutions. On the other hand, the term "supplication" will be used in its most general meaning with reference to letters (or documentation) which single citizens, or organized and recognized groups, sent to the state authorities requesting grace, favours, privileges, or calling attention to injustices and abuses. These documents gave rise to legal proceedings,

\footnotetext{
* The research reported in this paper is part of the project "Petitions and Supplications in Early Modern Europe: Fifteenth-Eighteenth century" currently under development at the Istituto storico italo-germanico di Trento. The project is coordinated by Andreas Würgler and the author. Many thanks to Friederike Oursin for the translation into English.

I. The "Sistema politico universale delli Ducati di Parma e Piacenza" is an anonymous report ascribed to a government official and expert in administrative matters; it was presumably compiled between 1737 and 1738 , and describes the juridical and administrative procedures of the duchies in the Po valley as they developed during the period of the Farnese dynasty. See Sergio Di Noto (ed.), Le istituzioni dei Ducati parmensi nella prima metà del Settecento (Parma, 1980), p. I09; Paola Repetti, "Scrivere ai potenti: Suppliche e memoriali a Parma (secoli XVIXVIII)", Sogittura e civiltà, 24 (2000), pp. 295-358.
} 
administrative acts that led to proceedings in tribunals, magistracies, and chancelleries. ${ }^{2}$

In the central and northern Italian states of the early modern period, just as in the rest of Europe, the use of petitions and supplications - the quest for a direct relationship with the authorities - was one of the main approaches to the relation of power, of communication between the rulers and those ruled. ${ }^{3}$ As a result, special agreements with individuals or groups came about; respect for statutes, habits, and local or class privileges was established; grace was conceded ad personam; remissions of punishments, subsidies, extensions of payments due, and the execution of laws were granted. Given the relatively small size of the Italian states, managing power in a paternalistic and personal fashion could persuade subjects to opt for a form of agreement or mediation, for a compromise solution rather than a resort to more violent forms of opposition and rebellion, which did occur but hardly ever extended beyond local or civic level. ${ }^{4}$

\section{THE SOVEREIGN PRINCE AS THE FATHER AND FOUNDATION OF JUSTICE AND GRACE}

In order to understand the development of supplications as a privileged form of communication between subject and authority, it is useful to look at the idea of regality, the prerogatives, the myth, and its representations in philosophical political literature, in social behaviour, and in government practice. The sovereign is in turn father, judge, legislator, and reference point of justice and of fairness, to whom subjects can turn. These are ideas,

2. For general historiographic indications see Andreas Würgler, "Voices from the Silent Masses': Humble Petitions and Social Conflicts In Early Modern Central Europe” in this issue, pp. I I-34; Beat Kümin and Andreas Würgler, "Petitions, Gravamina and the Early Modern State: Local Influence on Central Legislation in England and Germany (Hesse)", Parliaments, Estates E Representation, I7 (1997), pp. 39-60; Andreas Würgler, "Suppliken und Gravamina: Formen und Wirkungen der Interessenartikulation von Untertanen in Hessen-Kassel 1650I 800", Geschichte als Argument. Skriptenheft II. IV Frühe Neuzeit. V. 19. und 20 Jabrhundert (Munich, 1996), pp. 9- Io; the essays by Renate Blickle, Rosi Fuhrmann, Beat Kümin, Andreas Würgler, André Holenstein in Peter Blickle (ed.), Gemeinde und Staat im Alten Europa (Munich, 1997), pp. 24I-357; Andreas Würgler, "Suppliche e "gravamina" nella prima età moderna", Annali dell'Istituto storico italo-germanico in Trento/Jabrbuch des italienischdeutschen historischen Instituts in Trient, 25 (1999), pp. 5 $15-546$.

3. The central and northern Italian states of the early modern period had relatively small territories: the Savoy state (Turin), the state of Milan, the ecclesiastical principality of Trent, the Este state of Modena and Piacenza, the Grand Duchy of Tuscany, the Republic of Venice, and the Republic of Genoa. For an introduction and a general bibliography see Giorgio Chittolini, Anthony Molho and Pierangelo Schiera (eds), The Origins of the State in Italy, 1300-1600, in The Journal of Modern History, 67, Supplement (1995).

4. For the Italian states, specific research on petitions and supplications is still in short supply in spite of the full archives. Here, I only wish to present some lines of research and outline the problem in a general fashion. 
myths, that cannot refer to an anonymous or generic institution but need to be embodied in a physical person, the leader, the supreme representative of a community, a collective identity, a state. ${ }^{5}$ From here stems the fact that supplications are preferably addressed directly to the supreme authority, even if the supplicants themselves know that their demands will be subject to filters and procedures, and that minor officials and expressly delegated magistracies will evaluate them.

In any case, the prince should not be confused with the body of tribunals, parliaments, and magistracies of any degree. This may partially explain why, in the petitions and supplications, also in moments of serious conflict (e.g. in cases of revolt or rebellion), it is excluded outright that the prince be held directly responsible for the injustices that are the cause of the rebellion. All the responsibility must fall upon persons and positions of lower standing (corrupt officials), while the relationship of trust and of filial obedience with the prince is to be preserved and confirmed. Laws, regulations, and officials can be unjust and corrupt - never the prince. Countless examples could be given here. Supplicants had to respect and comply with certain rules of conduct, which were both symbolic as well as eminently strategic and practical, whether they were addressing supplications to the highest authorities in an ultimate and extreme attempt to obtain justice, or whether a revolt was already under way. A remarkable example is the interpretation - or the many possible interpretations - of the people's "political loyalty" during the most important Italian revolt of the seventeenth century - in Naples from I647-1648.

In July I 647, during the early stages of the revolt led by Masaniello, the attitude of the Neapolitan people towards the authorities was the object of concern, and of contradictory interpretations. This emerges from the accounts sent to the King of Spain on behalf of the Duke d'Arcos, the viceroy of Naples:

The origin of all this lies in the mortal hatred that the innumerable people of Naples and the Kingdom harbour against the Nobility, justly accumulated because of the violence it has already inflicted and because of the oppression of the taxes which it cannot sustain alone. And thus, as a feeling cradled in the hearts

5. For some examples of how this idea - espoused by the population - is still alive and well in Western societies, see the letters to the President of the French Republic in the 1970s, in YvesMarie Bercé, Le roi caché. Sauveurs et imposteurs: Mythes politiques populaires dans l'Europe moderne (Paris, 1990), pp. 4 I 2-4 I 5; for Italy, Camillo Zadra and Gianluigi Fait (eds), Deferenza rivendicazione supplica: Le lettere ai potenti (Treviso, I99I). For one of the forms of supplication in contemporary society, see Didier Fassin, "La supplique: Stratégies rhétoriques et constructions identitaires dans les demandes d'aide d'urgence", Annales. Histoire, Sciences Sociales, 55 (2000), pp. 955-98 I.

6. On the Neapolitan revolt from I647 to I648, see especially Francesco Benigno, Specchi della rivoluzione: Conflitto e identità politica nell'Europa moderna (Rome, 1999), pp. 199-285. The Kingdom of Naples was under the Spanish monarchy from i 503 onwards. 
for a long time, the hate has violently exploded at the first blow. But the people have in truth shown strong loyalty and love for Your Majesty. They bowed their flags to Your Majesty's portraits, the ones taken from the very houses they had burned, and always said "viva il Re" and "viva la Spagna". In addition, towards me they have shown no hate because at the same time they kept repeating "viva il duca d'Arcos". Of course, one remains in visible danger and the service of your Majesty is in the hands of a furious people who obey an uncultured man, without good sense and reason [Masaniello].7

The Neapolitan people's symbolic gestures of loyalty to the sovereign were indisputably ambiguous, but they reflect the attempt - even in open rebellion - to keep a certain distance, or to avoid the accusation of rebellion, of high treason. ${ }^{8}$ The people did not act against the King of Spain, therefore, but rather to re-establish a justice denied in his name. Even diverse and contradictory forces and aspirations - different goals worth fighting for - could crystallize around the principle of loyalty to the supreme authority. During the course of the revolt in reality, as its political objectives became clearer and more radical, this principle was overturned. The political models aspired to were no longer sovereignty and the monarchy, but rather the republics: firstly the myth of republican Rome, but also, much more concretely, analogous contemporary European phenomena, namely the liberty and patriotism of the Swiss, as well as the Dutch and Portuguese revolts. In the same manner, the principle of "loyalty" to the monarchy was exposed as a "cruel burden leading to extreme poverty", to which the political form of the republic opposed itself - freedom in place of tyranny. ${ }^{9}$

The principle of loyalty referred to here was part of a widespread "political culture". In literature dedicated to the "good prince", "good government", "government of the home" (oeconomica) - topics that were widely discussed throughout the early modern period in Italy - the prince is represented as the father of that group of families which makes up the state. His qualities must correspond to those of a good paterfamilias. Above all, he needs to be just and mindful of the wellbeing of those

7. Letter from the Duke d'Arcos, Viceroy of Naples, to the King of Spain, Naples, is July i 647 , printed in the appendix to Rosario Villari, Per il re o per la Patria: La fedeltà nel Seicento (Rome [etc.], 1994), pp. I 50-I I.

8. On the juridical construction of the offence of high treason and on its political use, see Mario Sbriccoli, Crimen laesae maiestatis: Il problema del reato politico alle soglie della scienza penalistica moderna (Milan, I974).

9. These ideas are expressed in a pamphlet with the title "Ragionamento di Tomaso Aniello [Masaniello] Generalissimo per eccitare il suo Popolo napoletano alla libertà", published in an appendix to Villari, Per il re o per la Patria, pp. 67-72, 69. On the great number of writings regarding the analysis of European revolutions in the $\mathrm{i} 640 \mathrm{0}$, many of which are written in Italian, see Peter Burke, "Some Seventeenth-Century Anatomists of Revolution", Storia della Storiografia, 22 (1992), pp. 23-35. 
entrusted to his care in respect of "natural" and given roles and hierarchies. But the prince is also identified as supreme judge, peacekeeper, source of arbitration, distributor of justice, and dispenser of grace, to whom one may turn in order to seek favours and privileges, derogations to laws and norms, exceptions, deferment, right up to the ultimate entreaty, i.e. that of grace capable of revoking a death sentence. ${ }^{10}$

Cosimo I De Medici, Grand Duke of Tuscany (I I I9-I 574), can be seen as the example of an Italian prince whose politics were characterized by the wish to intervene directly and personally in criminal and civil justice, as well as by the pursuit of a direct and personal relationship with his subjects. In a letter of I 568 , addressed to the Magistrato supremo, the highest court and political organ of the state (written when Cosimo I had already handed over government functions to his son, Francesco), the duke clearly states those rules of good conduct which, according to him, ought to govern all relations with subjects. It is the prince's duty to build and maintain a trusting relationship with his citizens and subjects, a relationship whose validity is warranted by the easiness and freedom with which the latter can turn to their prince and manifest their needs. In addition, the supplication - the letter personally addressed to the prince - is identified as the "quickest", "most secure", and "most secret" means to achieve the "public and private benefit", the "common and individual good":

When we [Cosimo I] left the government of our States - and some years have already passed since - we had established a good custom, which was highly appreciated by our citizens and by all of our subjects. The [custom] was that any kind of person, for comfort and facility in negotiating, could write to us and have the letter arrive in our hands. From this many good results ensued. Everyone could always reach us and they could be certain, that no one would ever come to know that which was written and in this way we could come to know what was communicated and they [the citizens and subjects] could speak their mind without anyone else, except for us, knowing it [...]. From this it followed that, once we understood what was necessary, we provided as we thought best for the common and individual good of those who wrote to us.

$[\ldots]$ For this reason, with this [letter] of ours we [...] wanted to make you see that we [Cosimo] and the prince [Francesco] will always be very happy to see these letters and that no one else will see them and that we shall then see to the needs, public or private as they might be, with that love that you have come to

Iо. Daniela Frigo, "La dimensione amministrativa nella riflessione politica (secoli XVIXVIII)", in Istituto per la scienza dell'amministrazione pubblica, L'amministrazione nella storia moderna, 2 vols (Milan, 1985), vol. I, pp. 21-94; António Manuel Hespanha, "Justiça e administração entre o antigo regime e a Revolução", in Bartolomé Clavero, Paolo Grossi and Francisco Tomas y Valiente (eds), Hispania entre derechos propios y derechos nacionales, 2 vols (Milan, I990), vol. I, pp. I35-204. 
know from the results [obtained] in the many years we have governed you. And the prince shall do the very same [...]. ${ }^{\text {II }}$

Arguably, the idea of a sovereign who is protective, and acts as an attentive father to the vast family that makes up the state, reaches its most complete expression in enlightened absolutism. In this very period around the middle of the eighteenth century - an immense effort of indoctrination was under way, affecting all the people, through traditional instruments such as catechesis and preaching, but also (much more than in the past) through schools and primary education, now open to social classes that had been excluded from instruction before. The following is but one indicative example, taken from a reader for school children in the northern Italian territories of the Habsburg monarchy. The chapter dedicated to patriotism and to the love of one's country contains all the topoi of the mythology of the sovereign taking special interest in the problems his subjects place before him "orally or in writing":

In the State, the monarch directs and arranges all things for the highest good. $\mathrm{He}$ ensures that order, abundance, and comfort reign everywhere. [...] He is the loving father of that great family, which makes up the State. He perceives the miseries and the afflictions of the subjects and he does not shun the fatigue of having them made known to him, be it orally, or in writing. He leaves no one without help or succour, the examination and the circumstances allowing. $\mathrm{He}$ forgoes rest, happiness, and comfort in order to attain peace and comfort for his subjects. ${ }^{\mathrm{I2}}$

\section{SUPPLICATIONS TO THE “PAPAL PRINCE” AND THE ROMAN CURIA}

The Pope, the sovrano pontefice, was a special kind of Italian prince. His double nature as spiritual leader of the Catholic Church and secular prince of the papal state made him the religious authority, but it also allowed him to exert social and political influence in the Italian states. It is in the person of the Pope that one can see most clearly the dissolution of the boundary between justice and grace - i.e. the boundary between crime, understood as disobedience to civil and political law, and sin, understood as disobedience to moral or religious law. Even though the two realms remained separate, at least theoretically, by the end of the Middle Ages any

I r. The letter of Cosimo I is transcribed in Elena Fasano Guarini, "Considerazioni su giustizia stato e società nel Ducato di Toscana del Cinquecento", in Sergio Bertelli, Nicolai Rubinstein, and Craig Hugh Smyth (eds), Florence and Venice: Comparisons and Relations, vol. 2, Cinquecento (Florence, I980), pp. I35-168, I43-I44.

I 2. Libro di lettura per gli scolari delle scuole italiane nelle città, borghi terre e più grandi villaggi degl' imp. reg. dominii. Tomo secondo, Consistente nell'introduzione alla probità e rettitudine. Tradotto dal tedesco dal sacerdote Giovanni Marchetti (Rovereto, I795), p. IоI. 
difference between spiritual power and secular power, between jurisdiction and grace, tends to disappear in the highest supreme acts executed personally by the Pope. In the same manner, the distinction between the tribunal of conscience, of moral and religious sins/crimes (from which absolution is obtained by way of oral or written confession) and the judicial tribunal becomes less pronounced. ${ }^{\mathrm{I} 3}$

If we take a look at the organization of the Roman Curia, it is not easy (if at all possible, given the current state of research) to reconstruct the complex multitude of tribunals and congregations, to distinguish those of the papal state and the city of Rome from those directed at "Christianity", and to account for their complicatedly intertwined competences. ${ }^{14}$ Generally, it can be said that almost every proceeding, every decision, every sentence or concession of grace had its origin in a supplication. The convoluted machinery of the curial offices can be taken as an example of a precocious and generalized organization of the "supplicational system", if one bears in mind that 7,365 volumes of the series Registra supplicationum are kept in the Archivio Segreto Vaticano, relative to the period dating from I 342 until I 899. ${ }^{\text {IS }}$ Another systematic and impressive series of registers of supplications is kept in the Archives of the Sacra Penitenzieria Apostolica. ${ }^{16}$

Especially after the Council of Trent (1545-1563), following the amplification of Roman centralization to the detriment of the powers and prerogatives of bishops and local tribunals, a growing number of followers and subjects had to turn to Rome. One had to do so in order to obtain absolutions, dispensations, sentences, and graces for transgressions of a sexual and matrimonial nature (abortion and infanticide, incest, rape, sodomy, marriage between blood relations); for questions pertaining to

I3. Overall, on the development of the papal state and the papal Curia in the first centuries of the modern period see Paolo Prodi, The Papal Prince: One Body and Two Souls: The Papal monarchy in Early Modern Europe (Cambridge, 1987). On sins/crimes see Elena Brambilla, Alle origini del Sant'Uffizio: Penitenza, confessione e giustizia spirituale dal medioevo al XVI secolo (Bologna, 2000); Paolo Prodi, Una storia della giustizia: Dal pluralismo dei fori al moderno dualismo tra coscienza e diritto (Bologna, 2000).

I4. On the organization of justice in the city of Rome see, in particular, Peter Blastenbrei, Kriminalität in Rom I560-I585 (Tübingen, 1995); on the supplications to the Roman Curia see Irene Fosi, "Sovranità, patronage, e giustizia: suppliche e lettere alla corte romana nel primo Seicento", in Gianvittorio Signorotto and Maria Antonietta Visceglia (eds), La corte di Roma tra Cinque e Seicento "teatro" della politica europea (Rome, I998), pp. 207-24I.

I s. Bruno Katterbach, Inventario dei registri delle suppliche (Vatican City, 1932).

16. On the Sacra Penitenzieria see Ludwig Schmugge, Patrick Hersperger and Béatrice Wiggenhauser, Die Supplikenregister der päpstlichen Pönitentiarie aus der Zeit Pius'II (14581464) (Tübingen, 1996); many transcriptions of supplications to the Penitentiary can be found in Filippo Tamburini, Santi e peccatori: Confessioni e suppliche dai Registri della Penitenzieria dell'Archivio Segreto Vaticano (145I-I586) (Milan, 1995), and in Filippo Tamburini and Ludwig Schmugge (eds), Häresie und Luthertum: Quellen aus dem Archiv der Pönitentiarie in Rom (I5. und I6. Jabrbundert) (Paderborn [etc.], 2000). 
ecclesiastical organization and discipline (benefices, pensions, establishing monasteries or new churches, entering into a monastery, becoming a cleric); and for questions of a moral-economic nature, such as usury. The list could be continued to include almost every aspect of the religious and social life of the clergy, lay people, and ecclesiastical institutions. All this necessarily led to Rome, to the central authorities of the Catholic Church where the knowledge of sins and crimes, the judgment of guilt, the possibility of intervening, regulating, punishing, and absolving were centralized.

The courts and the congregations called to deal with the examination of the supplications were primarily the Signatura of Justice, the Signatura of Grace, and the Dataria apostolica, which becomes more and more important by the end of the seventeenth century. ${ }^{17}$ The reforms of Sixtus V (I $585-1590)$, however, extended the handling of supplications to other major congregations of cardinals that could deliberate freely or propose their acceptance. ${ }^{18}$

Normally, supplications were letters or documents standardized according to the style of the Roman Curia, and the course of the documentation - from the presentation of the supplication to the papal decision - was long, complex, and expensive. ${ }^{19}$ A completely different outcome was reserved for those supplications that could count on influential sponsors at court - members of the Pope's family; cardinals, and prefects of the congregations; members of the aristocracy, or of the feudality of the Catholic states; members of the Roman patriciate, or influential figures of the curial or financial oligarchies. All those who could pride themselves on relations of familiarity, service, direct or indirect acquaintance with cardinals, or with the Pope's family - in other words, with those who were inside the net of patronage or clientele of the papal court - could place their hopes in a system of justice that, in many cases,

17. Niccolò Del Re, La Curia romana: Lineamenti storico-giuridici (Vatican City, 1998), pp. 2 I $2-225,447-454$.

I8. Thomas Frenz (ed.), I documenti pontifici nel Medioevo e nell'età moderna (Vatican City, 1989), p. 75, or idem, Papsturkunden des Mittelalters und der Neuzeit (Stuttgart, 1986).

19. By the beginning of the thirteenth century, supplications began to be presented not only orally but also in writing, and very soon forms were introduced to facilitate their examination as well as the verdict, such as, e.g., Cardinal Guala Bicchieri's Libellum de formis petitionum secundum cursum Romanae Curia. In I33 I, the constitution Paterfamilias specified fifty-three types of requests that could be received by the papal Chancellery: see Jacques Verger, "Que peuton attendre d'un traitement automatique des suppliques?", in Lucie Fossier, André Vauchez and Cinzio Violante (eds), Informatique et histoire médieévale (Rome, I977), pp. 73-78, 73; Bernard Guillemain, "Une opération en cours: le traitement informatique des suppliques d'Urbain V", in Paolo Vian (ed.), L'Archivio Segreto Vaticano e le ricerche storiche (Rome, I983), pp. 193-205, I99. 
could prove to be solicitous, efficient, and quick. ${ }^{20}$ One example: when on 3 I August I 623 the Bolognese noblewoman, Artemisia Duglioli Ghisilieri, wrote to the newly-elected Pope, Maffeo Barberini (Urbano VIII), who was a relative of hers as well as a long-standing friend, asking for justice in favour of her nephew Cesare Ghisilieri ("well-known at the Roman court for having served Cardinal Farnese for fifteen years") who had been assassinated by a priest, the answer was not long in coming: on I4 September, Artemisia could thank the Pope for "having given the order to begin the trial against the imprisoned delinquent and for having the proceedings sent to Rome". ${ }^{21}$

\section{A SPECIAL KIND OF SUPPLICATION: THE ANONYMOUS DENUNCIATION}

Openness and secrecy, public moments and private moments, speech and writing - these, then, were among the essential expressions of the relationship between subjects and sovereign which passed through the via supplicationis. It should not be forgotten, however, that in the centuries of the early modern era, along with the written supplication, the ceremony of the audience survived, i.e. the possibility of personally appearing before the prince to present individual or collective requests. ${ }^{22}$

In contrast, a right that could not be waived was the "most secret way" to use an expression of Cosimo I - that is, the guaranteed rights to inform the prince about personal or family needs, to voice complaints, to denounce injustices or abuse, to ask for or to propose special interventions, in private form, without "publicity". A letter's private nature protected the supplicants from the (not so remote) possibility of becoming the object of an investigation, of running personal risks, of exposing themselves to threats, intimidation, and vendettas. From the position of power,

20. This also depended on the unique character of the papal "monarchy", the discontinuity between one papacy and the next: each change of pope brought with it not only a change in the goals of a religious nature, but also a whole new series of political ties and allegiances, a change in clientele, new career possibilities at the Roman court, in the papal state, and in the ecclesiastical structure of the Catholic world; Renata Ago, Carriere e clientele nella Roma barocca (Rome [etc.], I990).

$2 \mathrm{r}$. Fosi, "Sovranità, patronage, e giustizia", p. 220. In particular, she points to the mediation role of noble and patrician women in defence of the family honour.

22. On the public manner of administrating justice on behalf of the French sovereign, see Sarah Hanley, The Lit de justice of the Kings of France: Constitutional Ideology in Legend, Ritual, and Discourse (Princeton, NJ, 1983). In the papal state the restoration of the public audience from I69I to I695 by Pope Innocent XII (I69I-I700) created great expectations but scarce practical results in the administration of justice, and did not last long; see Claudio Donati, " 'Ad radicitus submovendum': Materiali per una storia dei progetti di riforma giudiziaria durante il pontificato di Innocenzo XII", in Bruno Pellegrino (ed.), Riforme, religione e politica durante il pontificato di Innocenzo XII (I69I-I700) (Galatina, I999), pp. I59-178, I63-I64. 
guaranteeing secrecy not only promised a more direct perception of social and territorial problems, but it also made it easier to control the population's ideas, moods, and feelings with regards to the authorities. From this point of view, it is not so strange that anonymous letters - and especially denunciations - received almost the same treatment as signed supplications.

Supplications and anonymous letters were two pillars of the government system and the relationship between ruled and ruler throughout the entire ancien regime in the republic of Venice, and the importance of anonymous letters is on a par with that of supplications. The system of secret denunciations was praised as a truly unique instrument for determining the truth and for protecting the republic's safety. The system of denunciations made it easy for the authorities to acquire "the universal cognition of the important things and the happiness of the State". ${ }^{23}$

In the republic of Genoa, around the middle of the seventeenth century, the use of lettere orbe - anonymous letters of denunciation - increased dramatically. This is to be attributed to a strengthening of their official political reception, so much so that 60 per cent of the letters from Genoa and 80 per cent of those from the rest of the territory led to administrative or judicial action. ${ }^{24}$ The anonymous letter-writers also requested more attention from the authorities for their kind of document. They demanded that the form of communication represented by the anonymous letters be taken into account by the authorities in exactly the same way as supplications written by lawyers, or as those events that reflected vendettas or private forms of justice, such as throwing stones or dung at houses and front doors. ${ }^{25}$ The two most common reasons given for writing anonymous letters were closely connected: on the one hand, there was the desire to denounce a crime for "obligation of conscience" so that justice may be done; on the other hand, there was the desire to avoid "attracting hate and living in anxiety". ${ }^{26}$ Faced with an impotent or conniving justice, the anonymous supplication became, at times, the only possible form of denunciation for crimes, private forms of violence, arbitrary or deviant behaviour, which so often remained secret or went unpunished due to the social rank or protection of the accused.

23. This is asserted in the eighteenth century by Marco Foscarini ( $1696-1763)$ nobleman, official historiographer and Doge of Venice $(1762-1763)$; Paolo Preto, I servizi segreti di Venezia (Milan, I994), pp. 170-17r. More generally, on the system of denunciations, the bocche di leone, made of stone and located inside the palazzi of the magistracies, and the governing organs in Venice and the territory designated expressly for receiving anonymous letters, see ibid., pp. I68I77.

24. Not only did the majority of anonymous letters have consequences, moreover, the "voices", the information orally compiled, could suffice for undertaking administrative or legal action; Edoardo Grendi, Lettere orbe (Palermo, I989), p. 84.

25. Anonymous letter sent 1607; Grendi, Lettere orbe, p. I2.

26. Ibid., p. I3. 
Still in Genoa, beginning with the year I 607 with the legge dei biglietti ("law of the notes"), the principle of anonymity received a kind of political legitimacy and specific regulation. The task of evaluating the anonymous denunciations was delegated to the Consiglio Minore, an organism composed of 100 aristocrats. It was to deliberate and check the denunciations for a growing number of crimes such as bearing arms, protecting bandits, insolence, and fiscal fraud. The same procedure was extended to a series of typically aristocratic crimes such as occult crimes to verify public opinion (I6I2), fighting duels (I64I), games and betting, or other manoeuvres for electing the Doge (I642). ${ }^{27}$

\section{THE WAYS OF SUPPLICATION}

If this was the understanding and positive evaluation reserved for anonymous letters, supplications were given even greater consideration. To follow the institutional itinerary of a supplication - from the draft to the rescritto ${ }^{28}$ - is no simple task, because the norms and regulations are not organically collected but need to be followed in decrees, chancellery manuals, and collections of answers to supplications (rescritti) often compiled for internal office use. ${ }^{29}$

The supplications to the highest authorities of the state were distributed to various magistracies and offices; and, for every supplication, sometimes lengthy and complex procedures were begun. In Venice, the Consiglio dei Dieci (The Council of Ten - the republic's most important politicaljudicial organ) also had the task of "filtering" the correspondence that came from the authorities of the territory and from subjects, on the one hand, and from other supreme institutions, such as the Collegio, the Signoria, and the Consiglieri, on the other. ${ }^{30}$ The Collegio, especially, was

27. Ibid., pp. is-16.

28. Rescritto: the prince's written answer to a subject's request. If, in old canon law, the term was uniquely used for the Pope's written answers, beginning with the Middle Ages its use was expanded, insofar as the answers written by those who had legislative or jurisdictional power were also called rescritti.

29. A number of very interesting topics that cannot be addressed here are those connected with the first fundamental passage of the supplication: the mechanisms of writing, the linguistic aspects, the strategies of the discourse, the material compiler of these documents, the mechanisms of transmission to the rulers. For these aspects, as well as for an analysis of the supplications' contents, specific archival research is necessary. On the linguistic and formal aspects of the supplications see Paola Repetti, "Scrivere ai potenti"; Maria Nadia Covini, "Vigevano nelle carte dell'auditore: Aspetti dell'intervento ducale nell'amministrazione della giustizia", in Giorgio Chittolini (ed.), Vigevano e i territori circostanti alla fine del Medioevo (Milan, 1997), pp. 303-324, 307-308.

30. Claudio Povolo, "Nella spirale della violenza: Cronologia, intensità e diffusione del banditismo nella terraferma veneta (1550-1610)", in Gherardo Ortalli (ed.), Bande armate, banditi, banditismo e repressione di giustizia negli stati europei di antico regime (Rome, 1986), pp. 2I-5 I, Pp. 43-44. 
a regulated body entrusted with, among other things, dealing initially with a large number of supplications, instituting the documentation, and dividing it among the various offices for evaluation. Accordingly, the supreme magistracies sorted the supplications and passed them on to the lower magistracies, especially bearing in mind the types of requests, contents, place of origin, the different offices' competences, but also the more strictly political priorities or appropriateness.

In the republic of Venice, for example, a supplication from German merchants reached the Consiglio dei Dieci in I604, requesting permission to carry arms in order to defend themselves against brigands, and it was passed to the Cinque Savi alla Mercanzia for evaluation. Some years later, a similar supplication from a group of Flemish merchants was passed from the Consiglio dei Dieci to the Podestà of Rovigo, in whose territory the merchants had been robbed. The case was entrusted to him, along with broad powers, such as the authority to proceed against the delinquents with inquisitorial process, and the possibility of offering immunity to those who denounced themselves for the crime. ${ }^{3 \mathrm{I}}$

The chancelleries of the various magistracies collected the documentation pertaining to the supplications, and much of this material, especially the rescritti sovrani, was judged to have value as a precedent (as in the case of judicial pronouncements) in guiding decisions in similar cases. In this way, collections of rules, manuals, and real treatises based on routine procedure were constructed, which became a corpus that we can define as normative, capable of making up for flaws in the legislation. ${ }^{32}$ One example is the Rituale, a text containing the collection of rescritti used by the magistracies in the Duchies of Parma and Piacenza, which presumably was compiled during the years of government of Ranuccio I Farnese (I592-I622) and subsequently expanded in the first half of the eighteenth century. ${ }^{33}$ The Rituale was a book that contained the formulae of the rescritti for criminal and civil cases, and had been compiled with the Prince's approval. Naturally, the presence of a formula in the Rituale suitable for the rescritto pertaining to a particular type of supplication did not entail its automatic application. Every supplication or memoriale was evaluated individually, and the rescritto was prepared only

[...] for those cases that will be held worthy of it and with the Prince's consent. Thus, there is a rescritto for any kind of homicide, but from this it does not follow that a supplication can be presented for all homicides, all thefts, and all capital offences; the rescritto will be used exclusively for those cases worthy of it. 34

31. Povolo, "Nella spirale della violenza”, pp. 2 I-23.

32. Luca Mannori, Il sovrano tutore: Pluralismo istituzionale e accentramento amministrativo nel principato dei Medici (Secc. XVI-XVIII) (Milan, I994), pp. 8-10, 4I 2-4I3.

33. Repetti, "Scrivere ai potenti", pp. 297-298; Di Noto, Le istituzioni dei Ducati parmensi, pp. $26-27,74$.

34. Di Noto, Le istituzioni dei Ducati parmensi, p. 74. 
In the second half of the sixteenth century, voices against the indiscriminate and generalized use of supplications were beginning to be heard. Furthermore, in the Duchies of Parma and Piacenza, for example, in the second half of the eighteenth century, writing memoriali, appeals, petitions, supplications, or letters addressed to "His Royal Highness" asking for justice or any other measure, had become such a widespread practice that it has been labelled an "intolerable abuse". Thus, a decree was proposed to take action by forbidding "anyone to present or pass on memoriali" to His Royal Highness, "regarding the affairs for which one can implore justice from judges and tribunals, and not even in those cases in which one can turn to the Dettatura, or the Congregation of Ministers". ${ }^{35}$ In the general climate of institutional and juridical reform, only the abuses were considered for reform - not the overall system of supplications.

By way of supplications, the rulers were informed about the needs and the necessities of a substantial part of the population. They felt a kind of "institutionalized obligation" to answer those social needs, to intervene in the private sector, and to take upon themselves the necessities of single subjects, of informal or institutionalized family groups, or organized groups such as the estates, religious associations, guilds, and communities. This form of communication - even in an ambiguous and subordinated fashion, not covered by a ruling or any form of certainty - allowed the supplicants not only to "humbly supplicate" but also to "come to terms" with the rulers. It gave them the chance to propose a strategy for the resolution of problems, to negotiate a reduction or modification of a sentence, by offering a "favour" or a service, a token of their working professionalism in exchange for a positive answer.

From the prisons of Venice, for example, hundreds of supplications reached the magistracies in which the supplicants and their families and protectors contrived reasonable exchanges or offered compensation worthy of being taken into consideration. In this manner, a former guard of the Venetian prison, himself jailed for homicide, offered to work as a guard for half the regular pay in exchange for his release. Others offered to reveal the names of thieves or to disclose escape plans or conspiracies in exchange for freedom. Prisoners sentenced to death obtained grace by offering themselves as executioners. ${ }^{36}$

Of course, those with trades essential to the state's economy, or whose occupations were not easily replaced, had higher contracting stakes. One

35. Daniele Marchesini, Il bisogno di scrivere: Usi della scrittura nell'Italia moderna (Rome [etc.], 1992), pp. 39-40.

36. Giovanni Scarabello, Carcerati e carceri a Venezia nell'età moderna (Rome, 1979), p. 37-38. For many examples of the most common requests sent to the Venetian magistracies by prisoners, see pp. 34-4I. 
famous case is that of the Florentine Benvenuto Cellini (I500-I57I), goldsmith, sculptor, architect, thief, sodomite, and murderer, whose artistic and criminal careers were punctuated with requests for grace and privileged treatment obtained from princes and popes, not for the wealth or nobility of his person but for his talent and artistic ability. ${ }^{37}$ However, this is not the only case of a man whose genius placed him above the law. ${ }^{38}$ In Venice, workers at the shipyards, condemned to one year in prison in I 594, managed to obtain a swift release after having simply endured a scolding. And a master of the mint was allowed to go to work in the daytime and return to prison only for the night. ${ }^{39}$

\section{"EXERCISING SEVERITY AND CLEMENCY"}

The medieval prince's prerogative as guarantor of the highest justice remains operative in the modern period while the other attribute of sovereignty - legislative power - has difficulties imposing itself. In fact, the juridical order is considered as given, already existing. The laws are not created ex novo but go back to tradition and custom, and they must be adapted in order to make them responsive to changed political situations in the government of territories, as well as in individual cases. Moreover, respect of custom is the best guarantee for peace and order. Starting with these principles, I think the characteristic of ancien-regime political systems based largely on supplications can be better understood: the rulers do not intervene in a "directive" sense but only in order to "correct", when their intervention is required..$^{\circ}$

The princes of the Italian states administered "extraordinary justice" by way of the supreme magistracies. In fact, not only cases pertaining to matters in some way connected to the prerogatives of sovereignty (feudal questions, taxes, privileges, etc.) were instituted and discussed in these

37. Paolo L. Rossi, "The Writer and the Man: Real Crimes And Mitigating Circumstances: Il caso Cellini", in Trevor Dean and K.J.P. Lowe (eds), Crime, Society and the Law in Renaissance Italy (Cambridge, I994), pp. I 57- I 83. See also The Autobiography of Benvenuto Cellini, George Bull (transl.) (Harmondsworth, 1973).

38. Pope Paul III writes in reference to Cellini: "You do not understand these things as well as I do. You should realize that men like Benvenuto, unique in their profession, must not be subject to the law"; Rossi, “The Writer and the Man", p. I8 3.

39. Scarabello, Carcerati e carceri, pp. 37-38.

40. On these topics see Paolo Grossi, "Un diritto senza stato (la nozione di autonomia come fondamento della costituzione giuridica medievale)", in Paolo Grossi, Assolutismo giuridico e diritto privato (Milan, 1998), pp. 275-292; Luca Mannori, "Introduzione”, in Luca Mannori (ed.), Comunità e poteri centrali negli antichi Stati italiani (Naples, I997), pp. 7-42; Mannori, Il sovrano tutore; Angela De Benedictis, "Giustizia, società, e corpi in età moderna: alcuni spunti di riflessione", in Angela De Benedictis and Ivo Mattozzi (eds), Giustizia, potere e corpo sociale (Bologna, 1994) pp. I I-22; Angela De Benedictis, Repubblica per contratto: Bologna: una città europea nello Stato della Chiesa (Bologna, 1995), pp. 2 I-105. 
institutions, but, more generally, petitions and supplications that required the prince's intervention. ${ }^{4 \mathrm{I}}$ Especially, cases regarding the lower social classes were to receive particular attention and protection (removing them from the competent magistracies if necessary) in accordance with the principle of "rendering justice to the poor" which - for example - had been clearly stated in the reform of the Tuscan juridical order of the end of the seventeenth century. ${ }^{42}$ For this reason, the same reform law set forth that in the treatment of cases before the supreme magistracy a precise order of precedence was to be respected: first came the procurator of the poor for the cases of the poor, then the women, then followed those "who were waiting", and last to be admitted were the foreigners. ${ }^{43}$ Just as the Este duchies of Modena and Piacenza had the Procuratore dei Poveri, a court appointed a defending counsel who - once the trial was over - had the duty of presenting to the prince a supplication for grace, or the reduction of the sentence in favour of the defendants. ${ }^{44}$

In all cases, exercising clemency, interpreting, and adapting the law to situations and persons is a prerogative reserved for the prince or the highest magistracies of the republic. For this, Grand Duke Cosimo I repeatedly accused the Nove Conservatori del Dominio e della Giurisdizione of Florence - the central magistracy responsible to the government of the territory - of excessive indulgence. He urged them to the strict application of the law, "wanting the graces to come from his majesty and not from the Magistrate, and that anyone be punished according to the infractions and without privilege". 45

The prince's presence could be judged by interpreting it positively or negatively in turn. In comparison with ordinary proceedings, which were slow, confused, and expensive, the supplication could be a short cut to justice, to obtain by way of grace that which could not be obtained by way of justice, or a means of filling in the gaps in the law. ${ }^{46}$ On the other hand, according to a high state official, the disorder in justice was to be attributed to a lack of specific laws. The primary responsibility for this lay with the

4I. Guarini, "Considerazioni su giustizia stato e società", p. I42.

42. Riforma generale e rinnovazione di leggi per tutti i magistrati e iusdicenti promulgated by Cosimo III in I678; Giuseppe Pansini, "Il Magistrato supremo e l'amministrazione della giustizia civile durante il principato mediceo", Studi senesi, 85 (1973), pp. 283-3 I5, 299.

43. Pansini, "Il Magistrato supremo", p. 304.

44. Carmelo Elio Tavilla, Riforme e giustizia nel Settecento estense: Il supremo consiglio di giustizia (I76I-I796) (Milan, 2000), p. 80.

45. Fasano Guarini, “Considerazioni su giustizia stato e società”, p. I4 I; Elena Fasano Guarini, "Potere centrale comunità soggette nel ducato di Cosimo I", Rivista storica italiana, 89 (1977), pp. $490-538,494-495$.

46. Pansini, "Il Magistrato supremo", p. 29I-292; Covini, "Vigevano nelle carte dell'auditore", p. 306; John K. Brackett, Criminal Justice and Crime in Late Renaissance Florence 1537-1609 (Cambridge, I992), p. 7I. 
princes because they elected to detain "the absolute power of exercising severity and clemency". ${ }^{47}$

Turning to the supplication, especially in judicial matters, is justified by the conception and practice of a form of justice where the arbitrium and the principle of negotiation play an elemental role. Sentences and penalties must consider the quality, role, and place taken in the social hierarchy by the accused - in a word, the individual's status. The supplication was an efficient instrument insofar as it allowed the modification, annulment, and reconsideration of sentences and punishment, evaluating both specific cases and the social hierarchy. This is explicitly declared, for instance, in the Sistema politico universale delli Ducati di Parma e Piacenza:

[By way of the system of supplications] when inflicting a certain punishment it is easier to find the best proportioned one not only for the case but also for the person. In fact, a penalty that is heavy for a common person can be minimal for a nobleman. In this way, after having inflicted a most severe punishment one has the possibility of reducing it according to the case under examination..$^{8}$

Petitions and supplications, therefore, modified the course of justice deeply in every phase: trial, verdict, and conviction. Following the presentation of a request for grace, the conviction could be substantially reduced or - in fewer cases - a complete remission of the penalty could be granted.

Even for serious crimes such as wounding or homicide, grace (i.e. a decrease of a fine, detention, or banishment, remission from capital punishment) could be obtained rather easily if the condemned stuck to a certain codified iter. The essential and unavoidable condition was obtaining la pace, that is to say, a notary deed - the Charta remissionis et pacis (letter of remission and peace) - with which the wounded or the family of the victim conceded pardon and reconciliation to the condemned.

Pace followed traditional procedures and rituals, which were more or less similar in different parts of Europe and which had a certain continuity throughout the whole ancien regime. In 1748 , in a valley of the Episcopal Principality of Trent, Pietro Torneri killed Salvatore Filosi. The latter had led a group of men to besiege Pietro's house, threatening to plunder it and kidnap his daughter. Torneri was condemned for homicide in a first trial. He then requested a revision and presented the notary document of peace (drafted as follows) to the court. Filosi's complete family, including women and children (all those present are mentioned in the notary deed) had been at the ceremony.

The closest relatives, then, 
$[\ldots]$ in their own name and in the name of the other blood-relations, on account of the prayers of Torneri, following the intervention of common friends and wanting to live according to the precepts of the religion, spontaneously, with cheerful spirit and pleased faces, after having drunk wine together, wishing each other health, declare a stable and irrevocable peace with Torneri, they forgive him that homicide and all the other offences received, promising not to damage him in any way and not to pursue the lawsuit brought forth against him with the criminal authority, which they beseech, on the other hand, to be benign in the sentence taking into consideration the motivations leading to the crime. And then, as a kind of compensation for that homicide (as had been arranged by the intermediaries) Torneri pays the Filosi 330 liras in silver, with which they declare themselves to be satisfied, plus a certain amount of grain, already entrusted to the widow. 49

Here we have all of the essential elements pertaining to documents of reconciliation and remission: the presence of everyone bound by blood ties to the dead victim, being his heirs; the friends or neighbours as witnesses and mediators of the agreement; the ceremony of drinking wine together; the declaration of the act's spontaneous nature; the setting of the amount of the damages. ${ }^{5}$

As peace was necessary for requesting grace, these documents could be subject to extortions, threats, or negotiations, and could be bought. In fact, some statutes, such as those of a number of towns in the Episcopal Principality of Trent, explicitly mentioned the "price of the peace" in proportion to the crime and to the reduction of the sentence, which could be obtained by presenting these documents. ${ }^{5}$

The requests for grace conveyed to the magistracies or the prince according to the importance or nature of the infraction were generally drawn up by a lawyer, according to a precise scheme. Here, following the elements of a linguistic and structural nature, the references to the nature of the crime and the magistracy which had handled the trial, there was the story of the crime itself, the declarations of possible penal precedents, the circumstances that might favour the reception of grace (errors or lacunae in the trial proceedings, repentance, poverty, banishment or prison suffered for a number of years, and so forth). Attached were the document of peace

49. The notary document's transcription and translation from Latin is taken from Giuseppe Papaleoni, Una composizione per omicidio nel 1749 (Trento, I 887), pp. I I-I 2.

50. Though the rituals of reconciliation always took place in the presence of a notary, they were not necessarily put in writing (and in this case it becomes more difficult to find traces in the archives or in the trial records). The ritual gestures - eating together, touching of hands, hugging or kissing in public - could be compared to the form of the public instrument; Ottavia Niccoli, "Rinuncia, pace, perdono. Rituali di pacificazione della prima età moderna", Studi Storici, 40 (1999), pp. 219-26I, 235-236.

51. Giorgio Politi, Aristocrazia e potere politico nella Cremona di Filippo II (Milan, 1976), p. 377; Papaleoni, Una composizione per omicidio, p. 9. 
and possibly the certificate of poverty, usually drawn up by the parish priest or a local official. ${ }^{2}$

It was not possible to request grace for every crime. Laws and statutes listed a wide range of crimes defined atroci (lese-majesty, heresy, sacrilege, blasphemy, sodomy, murder, parricide, robbery, counterfeiting money, etc.) for which it was not possible to request grace or any such request could have been considered only by the sovereign. ${ }^{53}$ Considering that only a little work has been done in this field for the Italian states, and that the judicial practices and laws partially differed from state to state, it becomes clear that the supplications for grace were actually quite common, but also extended to those crimes defined as atrociora which - because of their nature - seemed necessarily to lead to capital punishment.

Here are only two examples from politically different territories - Siena (a town subject to the Grand Duchy of Tuscany), and Bozen (part of Habsburg Austria). In both cases, the crime is "atrocious" - infanticide. In I765 in the territory of Siena, only one death sentence (by hanging from the gallows) was pronounced for infanticide but it was commuted to five years of prison by grace. ${ }^{54}$ One century earlier (I675), in Bozen, a woman was initially given the death penalty by the judge of Bozen, but obtained the conversion of the sentence to perpetual banishment from the court in Innsbruck. In any case, the sentence was extremely severe: in the seventeenth century, losing one's honour and being expelled from one's town was not all that different from death, but at least the women were not subjected to torture as provided for that crime by the Landesordnung (territorial law-code) of the Tyrol.ss

It is very hard to grasp the motivations for the concession or denial of grace by referring exclusively to laws and regulations. Customs, choices, and conveniences of a political, economic, and social nature must also be taken into account. Their weight can only be assessed with difficulty on a case-by-case basis; but they surely are quite relevant.

52. Politi, Aristocrazia e potere politico, pp. 377-378; Giovanni Liva, "Criminalità e giustizia nel Ducato di Milano tra Cinque e Seicento (I570-1630)", in Archivio di Stato di Milano (ed.), Aspetti della società lombarda in età spagnola, 2 vols (Como, 1985), vol. I, especially the documents on pp. 29-3I.

53. On the juridical aspects of the crimina atrociora see Luigi Lacché, “Ordo non servatus': Anomalie processuali, giustizia militare e 'specialia' in antico regime”, Studi storici, 29 (1988), pp. 36I-384; Politi, Aristocrazia e potere politico, pp. 379-380.

54. Laura Carli Sardi, "Analisi statistica sulla criminalità nel I 700 (reati e pene) con riguardo allo stato senese”, in Luigi Berlinguer and Floriana Colao (eds), Criminalità e società in età moderna (Milan, I991), vol. I2, pp. 327-475, 373.

55. The territorial law code of Tyrol in the sixteenth century, which was in force until the second half of the eighteenth century, decreed that women guilty of infanticide be buried alive and, upon death, impaled with an iron stake through the heart; Heinz Moser, Die Scharfrichter von Tirol: Ein Beitrag zur Geschichte des Strafvollzuges in Tirol von 1497-I787 (Innsbruck 1982), p. 102; Siglinde Clementi and Martha Verdorfer, Storie di cittadine: Bolzano/Bozen dal Medioevo ad oggi (Vienna [etc.], 2000), pp. 91-94. 


\section{TOWARDS THE MYTH OF THE STATE SUPER PARTES}

In these complex processes of communication between rulers and ruled, which runs along the via supplicationis, one can essentially locate the passage from the "myth" of the prince, as the supreme authority vouching for justice, to the "myth" of the state super partes. In ancien-regime societies, which were characterized by violence, feuds, and local conflicts, the prince, the sovereign, or the most important institutions of the republics embody a superior form of justice. An abstract entity, the state, with its offices, courts, and magistracies tends to become - or, if we prefer, to be represented and "justified" as - superior and equidistant with respect to the "parts": community and estate ties, families, relatives, clans, and factions. This holds true also in horizontal and vertical conflict situations or violence, which cannot be resolved from within, i.e., from inside the families or communities.

Communities often called on the central authorities to intervene against feudatories and local lords when their crimes or arbitrary acts remained unpunished and the communities turned out to be impotent. In I629, for example, "the poor and afflicted subjects", the men of Masone, a community of the Ligurian territory, sent a supplication to the Senate of the Republic of Genoa to expound the continuous vexations they are subjected to by Paolo Agostino Spinola, the feudal lord, defined as "a gentleman, otherwise of good mind, but in these circumstances perverted by passion". ${ }^{6}$ Involving the centre of power represented the ultimate and extreme possibility of obtaining an improvement of their conditions, but they had to complain in writing as they could not personally go to Genoa to sustain their arguments "because if they would have gone, they would have been tried for lese-majesty". This had been Spinola's threat, if only they had dared tackle the question. A meeting of the community to discuss the situation, in fact, ran the risk of being considered a "secret meeting and rebellion". Thus, the community's letter intended to anticipate possible actions in this direction. The men wanted to avoid the feudal lord turning to the central authorities first and asking for the intervention "of the regal arm and the supreme authority" for the repression of "rebels". The community itself also requested an external intervention, an envoy "as rigorous as possible, who can prosecute and punish as he sees just", however "independently", and who "must upon his return account to

56. This supplication is transcribed in Grendi, Lettere orbe, pp. 106-108. The men of the community accuse the feudal lord of forbidding them to extract their copper on penalty of imprisonment, of paying too little for coal, of inflicting new restrictions every day, such as, for example, not being able to sleep outside his jurisdiction for more than one night, not being able to leave the village without a special permit, not being allowed to buy even bread outside his jurisdiction. 
Your Most Serene Highnesses for the manner and form in which they are governed".57

The urban and rural communities, on the other hand, or the organisms representing rural communities, which had developed particularly in the northern Italian territories and states between the fifteenth and the sixteenth centuries, were often used by the central authorities in an antifeudal way. They could act as counterparts, as "interlocutors" in numerous and divergent cases - e.g. to intervene or regulate in local political and social competition, to mediate in conflicts (or also cause them to break out), to find adequate referents to whom the execution of laws and regulations, the collection of taxes, and so forth could be entrusted. ${ }^{8}$

In any case, this was not a progressive or inevitable organization of the territory, of the "peripheries" on behalf of the centre, but a complex political dialectic "fought with memorials, supplications, and protests". 59 The rural territorial organisms and the urban communities could refer to the capitoli di dedizione when they acted as interlocutors to the central authorities. In these documents, the communities and territories swore loyalty to the prince (or the republic) in exchange for the confirmation of certain autonomies, respect of statutes, customs and privileges. ${ }^{60}$ On the basis of this political understanding of a pact-based and contractual nature, petitions and supplications of a more political nature (against the actions of representatives of the central power, for example), or fiscal (against a tax increase), appealed to the respect of the capitoli di dedizione. In the same manner, the communities also appealed to the capitoli di dedizione to substantiate the correctness of the "right to resist": should the prince violate the agreements, the subjects are authorized to disobey and rebel. ${ }^{6 \mathrm{I}}$

57. Grendi, Lettere orbe, pp. 106-108.

58. For territorial representation of the rural communities see Giorgio Chittolini, Città, Comunità e feudi negli stati dell'Italia centro-settentrionale (secoli XIV-XVI) (Milan, 1996), especially ch. 7, "Principe e comunità alpine", pp. I27-I44, and ch. I I, "L'affermazione di Contadi e Territori”, pp. 2 I I-226. For the feuds among factions and the relationships between these and the central authorities of the states, see Edward Muir, Mad Blood Stirring: Vendetta and Factions in Friuli during the Renaissance (Baltimore, MD, [etc.] I993); Furio Bianco, "Mihi Vindictam: Aristocratic Clans and Rural Communities in a Feud in Friuli in the Late Fifteenth and Early Sixteenth Centuries", in Dean and Lowe, Crime, Society and the Law in Renaissance Italy, pp. 249-273; Angelo Torre, "Faide, fazioni e partiti, ovvero la ridefinizione della politica nei feudi imperiali delle Langhe tra Sei e Settecento", Quaderni storici, 2 I (1986), pp. 775-8 Io. 59. Chittolini, "L'affermazione di Contadi e Territori", p. 217.

60. Giorgio Chittolini, "I capitoli di dedizione delle comunità lombarde a Francesco Sforza", in idem, Città, Comunità e feudi negli stati dell'Italia centro-settentrionale (secoli XIV-XVI), pp. 39-60; more generally see Angela De Benedictis, "I contratti di potere come ragioni dello stato", in Pierangelo Schiera (ed.), Ragion di Stato e ragioni dello Stato (secoli XV-XVII) (Naples, 1996), pp. 67-93.

61. The relationships among patti di dedizione, petitions, and revolts need to be further investigated; see Giorgio Politi, "Rivolte contadine e movimenti comunali: Una tesi”, in Stefano 
Requests for intervention "from the bottom" consolidated the centre's power to intervene in the "peripheries". The state's growing invasive and bureaucratic presence accelerated the process of centralization, which had as long-term consequences the loss of "freedom" and the autonomies and traditional rights of communities. ${ }^{62}$ Not only the supplications of communities and groups called for a "weightier" presence of the state. Single persons turned to princes and magistracies in the hope that these might take on their personal problems - that, for example, they might intervene in favour of women, children, and weaker social classes against the power of family or social privileges. In other cases, the request for intervention was an implicit declaration of an impotence to resolve family conflicts "from inside". 63

In this context the supplications of widows in early modern Tuscany to the Magistrato sopra $i$ pupilli are significant. ${ }^{64}$ This magistracy was essentially responsible for administrating the patrimony of orphans, whose fathers had not left a will or appointed a guardian. But it also administrated the patrimony of persons considered physically or mentally unfit to administer the family estate responsibly. The system of transmission of the patrimony and the rights of tutelage of underage children provided that at the father's death, if no will had been made, the children were often removed from the mother and entrusted to the care of relatives of the father's. The procedure was the norm if the widow remarried. In order to keep their children with them and to obtain custody and the usufruct of their late husbands' patrimony, many widows appealed to the state

Gasparri, Giovanni Levi and Pierandrea Moro (eds), Venezia: Itinerari per la storia della città (Bologna, 1997), pp. I59-191; Giorgio Lombardi, La Guerra del sale: Caleidoscopio di una Historia, in idem (ed.), La guerra del sale (I680-1699): Rivolte e frontiere del Piemonte barocco, 3 vols (Milan, I986) vol. I, pp. 39-178, especially pp. 95-96, I I 8-I 22; De Benedictis, Repubblica per contratto.

62. Costanza D’Elia, “Supplicanti e vandali. testi scritti, testi non scritti, testi scritti dagli storici”, Quaderni storici, 3 I (1996), pp. 459-485 presents the supplications sent, in the first half of the nineteenth century, from certain communities in the province of Salerno (southern Italy) against land reclamation projects and, more generally, against the state's invasive presence in the local economy.

63. Le désordre des familles: Lettres de cachet des Archives de la Bastille présenté par Arlette Farge et Michel Foucault (Paris, 1982). On the supplication as a "tale" of individuality see Otto Ulbricht, "Supplikationen als Ego-Dokumente: Bittschriften von Leibeigenen aus der ersten Hälfte des 17. Jahrhunderts als Beispiel”, in Winfried Schulze (ed.), Ego-Dokumente: Annaherung an den Menschen in der Geschichte (Berlin, 1996), pp. I49-174.

64. The Magistrato sopra i pupilli was a magistracy instituted already at the end of the fourteenth century, completely reformed a century later, and again in 1565 . It remained operative until the beginning of the nineteenth century; Giulia Calvi, "Dal margine al centro: Soggettività femminile, famiglia, Stato moderno in Toscana (XVI-XVIII secc.)", in Società italiana delle storiche, Discutendo di storia: Soggettività, ricerca, biografia (Turin, 1990), pp. I03-I I8; Giulia Calvi, Il contratto morale: Madri e figli nella Toscana moderna (Rome [etc.], 1994). 
magistracies to defend themselves against the sometimes violent actions of their husbands' relatives. It is, therefore, the state "which legitimizes these women as interlocutors in family conflict matters, and begins granting the widows the right to take the word". ${ }^{65}$ Requests and negotiations were accepted as long as they conformed both to a code of behaviour and expression commonly accepted, and to the laws and regulations produced by the same magistracy (even if the prince could ask to have the last word and the final decision), which could differ from the family tradition, just as they could differ from the local and communal laws and statutes. But not only widows were involved in this kind of dealing. Over the course of time, stories emerge from the archives of the magistracies of women who matured into self-consciousness and acquired insight into their own needs and then tried to obtain their acknowledgement.

In 174I Caterina Guardi, a "poor girl and orphan" wrote to the Florentine magistrate. The girl was living in her father's house where she remained alone after the death of her father and her brothers, "not having wanted to get married or become a nun". Not being on good terms with her brother-in-law, who was trying to steal "some personal belongings she is fond of", she supplicated the magistrate to be left in "the free possession of the paternal goods, which are her maintenance, and of the increases, which she has managed to obtain". ${ }^{66}$

We do not know the outcome of the supplication. Perhaps a positive outcome for Caterina is inconceivable. But certainly, the request to be able freely to dispose of paternal patrimony, the refusal of the obligatory choice between becoming a nun or becoming a wife, is alone a sign of change. It is surely not - not yet - an inconceivable assertion of rights. But is a quest through a humble supplication addressed to the functionaries of the Florentine state - for a solution which ought to take into account and evaluate personal needs, individual and unique life stories. This goes against forms of behaviour, mentalities, traditions, and certainly laws and regulations considered (and often concretely applied as) objective and unchangeable entities.

65. Calvi, "Dal margine al centro", pp. Io5-106.

66. Idem, Il contratto morale, pp. 2 I0-2 I I. 